\title{
Effect of Stimulants on Biogenic Methane Formation and Dynamics of Bacterial Population
}

\author{
Pingkan Aditiawati ${ }^{1}$, Agus Pujobroto ${ }^{2}$, Indra Rudiansyah ${ }^{1}$ \& Harry Rahmadi $^{2}$ \\ ${ }^{1}$ Microbiology Study Program, School of Life Sciences and Technology, \\ Institut Teknologi Bandung, Jl. Ganesha 10, Bandung 40132, Indonesia \\ ${ }^{2}$ PT. Satui Basin Gas, Jl. Imam Bonjol No. 68, Jakarta 10310, Indonesia \\ Email: pingkan@sith.itb.ac.id
}

\begin{abstract}
Coal bed methane (CBM) is a renewable energy source produced through thermogenic and biogenic activity during the coal formation process. The aim of this research was to stimulate biogenic methane formation using simple carbon as stimulant. The microcosm set-up was done using subbituminous coal at $37^{\circ} \mathrm{C}$ in an anaerobic chamber. Stimulation with Naacetate, methanol, formic acid, and no additions, respectively, was carried out for 54 days; observation took place on day 2, 15, 24, 45, and54. The results of all treatments showed differences in the initial $\mathrm{pH}$ of the basal medium: $7.76(\mathrm{Na}-$ acetate), 6.69 (methanol), 4.06 (formic acid), and 8.95 (no stimultant), respectively. Addition of Na-acetate resulted in the highest methane formation rate $(5.034 \mathrm{mmol} / \mathrm{g}$ coal on day 24 of incubation), followed by methanol (4.377 $\mathrm{mmol} / \mathrm{g}$ on day 24 of incubation), formic acid $(2.520 \mathrm{mmol} / \mathrm{g}$ on day 22 of incubation), and no addition (1.2 $\mathrm{mmol} / \mathrm{g}$ on day 15 of incubation). Using denatured gradient gel electrophoresis (DGGE) it was observed that the microbial population dynamics of the microcosm depended on the stimulant. A decrease of bands indicated that the addition of Na-acetate and methanol had caused a decrease of bacterial diversity during the stimulation process compared to the control treatment (without stimulant).
\end{abstract}

Keywords: coal bed methane; denatured gradient gel electrophoresis; methanogenesis; stimulation; volatile fatty acids.

\section{$1 \quad$ Introduction}

Coal bed methane $(\mathrm{CBM})$ is a methane gas that is produced naturally during the coalification process. In contrast to other natural gases, CBM contains very little heavy hydrocarbons, such as propane and butane [1]. During the coalification process, methane gas can be formed through thermogenic and biogenic processes. Biogenic methane formation occurs through organic material decomposition from coal that is used as substrate for methanogenic bacteria to produce methane. Biogenic activity during CBM formation can be classified into three stages: (i) degradation of organic compounds from the coal into intermediate compounds; (ii) degradation of intermediate compounds into substrates for methanogenic bacteria; (iii) methanogenesis [2]. Methanogenic-

Received September 24 ${ }^{\text {th }}, 2013$,Revised November $28^{\text {th }}, 2013$, Accepted for publication November $29^{\text {th }}, 2013$. Copyright $\odot 2013$ Published by ITB Journal Publisher, ISSN: 2337-5760, DOI: 10.5614/j.math.fund.sci.2013.45.3.6 
bacteria such as Metanolobus sp., Methanosarcina sp., Methanobacterium sp., and Candidatus sp. are known for their role in methane gas formation during the coalification process [2].

Other bacteria also have an important role in CBM formation, for example syntrophic bacteria. Syntrophic bacteria are fermenting bacteria that degrade organic molecules from coal into organic acids and fatty acids that are used as substrate for methanogenic bacteria. Other bacteria that are involved in CBM formation are homoacetogenic bacteria, acetolastic bacteria, and metylotrophic bacteria. Under aerobic conditions, organic molecules from coal that are hydrolyzed by extracellular enzyme activity from bacteria produce intermediate molecules, such as fumarate, isoprenoid, and long-chain alkanes. These molecules degrade into acetic acid, fatty acids, methanol, hydrogen, and $\mathrm{CO}_{2}$ and are used as substrate for methanogenic bacteria [1].

Since methane gas can be formed through biogenic activity in coal reservoirs, the production of CBM can be improved by utilizing microbial activity to degrade organic molecules and convert intermediate molecules into methane. Biostimulation is a technique to stimulate indigenous microbial growth by injecting a nutrient into a coal reservoir, which can cause a change in bacteria diversity. This process can be used to reactivate a coal reservoir that is no longer active in producing methane gas [3]. The aim of this study was to stimulate biogenic methane formation by adding Na-acetate, methanol, and formic acid as stimulants. This study also analyzed changes in the bacteria community caused by the addition of these stimulants.

\section{Materials and Methods}

\subsection{Source of Coal Materials and Coal Proximate Analysis}

Coal of bituminous-subbituminous rank was obtained from CBM reservoir KB102, Asem-asem Basin in South Kalimantan. At reservoir KB-102 there are eight coal layers, consisting of five layers of inserts and three layers of coal seams. The coal sample was taken from the second seam layer at a depth of 607.05-607.25 meters. The sample was obtained by drilling a layer of soil to a depth of 585.5 to 643.5 meters. The sample was collected shortly after the core reached the surface and was placed into an anaerobic chamber that had been flushed with argon for microcosm treatment with different stimulants. Coal proximate analysis was done on site on air dried basis [1]. Figure 1 shows the profile of the coal layers from which the sample was collected. 


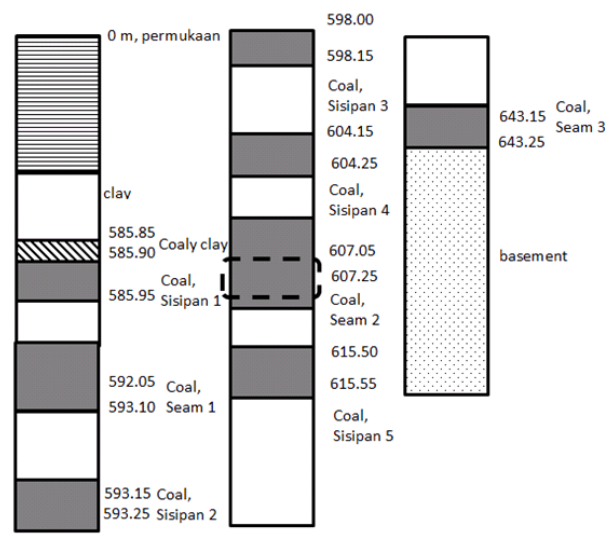

Figure 1 Profile of coal layers in CBM reservoir KB-102 [1]. The black dashed line shows the location where the sample was collected.

\subsection{Stimulation of Biogenic Methane Formation}

Biogenic methane formation was set up in a microcosm by adding different stimulants. Four types of microcosms were set up using $15 \mathrm{~g}$ coal core samples crushed into chunks $(1-2 \mathrm{~cm})$ under aerobic laminar conditions and $120 \mathrm{~mL}$ nutrient solution [4] and then treated by adding a different stimulant to each microcosm: $50 \mathrm{mM}$ Na-acetate, $5 \mathrm{mM}$ methanol, $50 \mathrm{mM}$ formic acid, and control (no addition). Each microcosm was flushed with $80 \%$ of nitrogen and $20 \%$ of $\mathrm{CO}_{2}$ and incubated at $37^{\circ} \mathrm{C}$ for 57 days.

Gas formation, volatile fatty acid (VFA), and $\mathrm{pH}$ were monitored by gas chromatography (Shimadzu ${ }^{\mathrm{TM}}$ ), with argon as mobile phase, on day 2, 15, 24, 45 , and 54 . The volatile fatty acid content was analyzed using the colorimetric method according to Montgomery [5]. During methane formation $\mathrm{pH}$ was measured by Eutech ${ }^{\mathrm{TM}}$ instrument $\mathrm{pH} 5$ [6].

\subsection{Effect of Stimulants on the Bacterial Community}

To analyze the bacterial community, bacterial DNA was isolated from the coal samples from the different microcosms on day 15, 24, 45, and 54. The samples were extracted, followed by amplification of the extracted DNA through PCR (Polymerase Chain Reaction) and separation of the PCR-generated DNA (DGGE method) [3,7]. The DGGE method allows the separation of DNA fragment mixtures of equal length based on their sequence-specific melting point in a polyacrylamide gel with a gradient of a denaturant chemical. From the number of DGGE bands, we can see the changes in the bacterial communities [7]. 
Bacterial DNA extraction was performed using the phenol-chloroform isoamyl alcohol method. The DNA solution was first extracted with a phenol chloroform isoamyl alcohol mixture (25:24:1) and then precipitated with absolute ethanol and Na-acetate. The DNA was pelleted, washed with $70 \%$ ethanol and resuspended in $50 \mu \mathrm{L}$ of TE buffer $\mathrm{pH} 8$. A nested PCR method was used for amplification of the bacterial genes encoding $16 \mathrm{~S}$ rRNA with $\mathrm{KAPA}^{\mathrm{TM}} 2 \mathrm{G}$ robust. Two types of primers were used: universal primers for the bacterial $16 \mathrm{~S}$ rRNA gene (338F-518R [3], 27F-1492R [8], 357F-907R [5]) and a specific primer for the methanogen 16S rRNA gene (357F-691R [6]). The PCR conditions used for primers 338F-518R, 357F-691R, 357F-907R were as follows: initial denaturation $\left(95^{\circ} \mathrm{C}, 5\right.$ minutes $)$, denaturation $\left(95^{\circ} \mathrm{C}, 30\right.$ seconds), elongation $\left(72^{\circ} \mathrm{C}, 15\right.$ seconds), and final elongation $\left(72^{\circ} \mathrm{C}, 2\right.$ minutes). Meanwhile, the conditions for each primer annealing were: $53^{\circ} \mathrm{C}$ for 15 seconds, $58^{\circ} \mathrm{C}$ for 15 seconds, and $50^{\circ} \mathrm{C}$ for 15 seconds, respectively. Amplification was run for 25 cycles.

The DGGE process was performed using the BioRad ${ }^{\mathrm{TM}}$ DGGE tool for mutation detection at 70 volts for 10 hours. Urea and formamide were used as denaturants. Polyacrylamide gel $(6 \%)$ was used with $35-70 \%$ denaturant concentrations for $550 \mathrm{bp}$ PCR product and polyacrylamide gel (10\%) was used with $35-60 \%$ denaturant concentrations for 180 bp PCR product. The DGGE results were stained using the silver staining method [7].

\section{$3 \quad$ Results and Discussion}

\subsection{Coal Proximate Analysis}

The proximate analysis of the coal samples from the Asem-asem Basin indicated that the coal could be ranked as subbituminous to bituminous based on the amount of carbon, volatile matter, and ash content (Table 1).

Table 1 Coal Sample Proximate Analysis.

\begin{tabular}{ccc}
\hline Variable & Amount & Subbituminous Standard $^{[\mathbf{1}]}$ \\
\hline Total moisture (air dried basis) & $3.32 \%-8.07 \%$ & \\
Fixed carbon & $11.88 \%-44.79 \%$ & $37 \%$ \\
Volatile matter & $20 \%-42 \%$ & $23 \%-24 \%$ \\
Ash content & $7 \%-65 \%$ & $20 \%$ \\
Calories & $2000 \mathrm{kcal} / \mathrm{kg}-7000 \mathrm{kcal} / \mathrm{kg}$ & $4396 \mathrm{kcal} / \mathrm{kg}$ \\
\hline
\end{tabular}




\subsection{Effects of Adding Stimulants on Biogenic Methane Formation}

\subsubsection{Na-acetate Stimulant}

The methanogenesis process started after 15 days (Figure 2A), as proven by VFAs reduction due to syntrophic bacteria activity, which converted VFAs into substrate for methanogenic bacteria. During the incubation period, the $\mathrm{pH}$ medium continued to increase ( $\mathrm{pH}>8$ after day 24). This led to conditions that were no longer optimum for methanogen growth and caused a decline in the production of methane gas. The increase of $\mathrm{pH}$ was caused by a high conversion of VFAs by syntrophic bacteria into acetate, formate, $\mathrm{CO}_{2}, \mathrm{H}_{2}$, or substrates of other methanogenic bacteria, as shown in Figure 2B. It was shown that in the early days of incubation (after 2 to 15 days), the VFA concentration increased and accumulated in the form of acetate, propionate, butyrate, and other VFAs. This was also observed in the study by Jones [4], where until 8 days of incubation, the increase of acetate accumulation indicated that acetate was the first organic compound released by the fermentative bacteria. The Na-acetate stimulated the activity of the methanogenic bacteria in methanogenesis, which caused VFA conversion into substrate for methanogenic bacteria to become more favorable thermodynamically, thus increasing syntrophic bacteria activity.

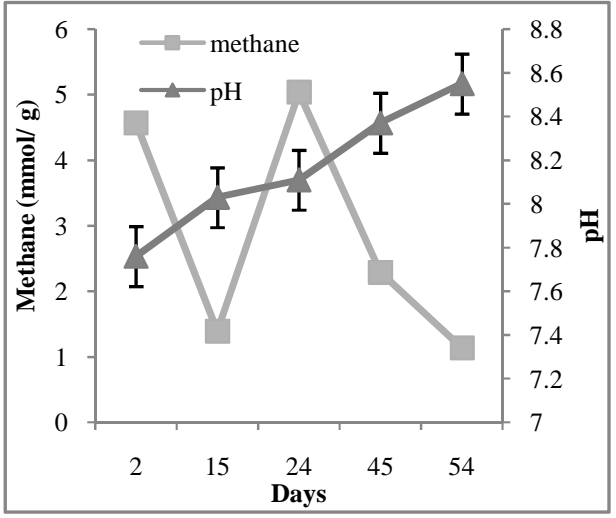

A

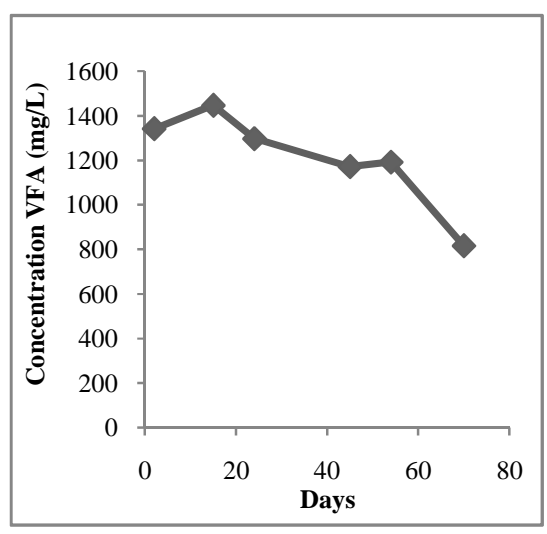

B

Figure 2 Methane production by adding Na-acetate stimulant. A = methane gas production; $\mathrm{B}=\mathrm{VFA}$ concentration from treatment with Na-acetate stimulant (conditions: $\mathrm{T}=37^{\circ} \mathrm{C}, \mathrm{P}=1 \mathrm{~atm}$, anaerobic, $120 \mathrm{~mL}$ media, $15 \mathrm{~g}$ subbituminous coal, $\left.\Phi_{\text {Coal }}=0.5-1 \mathrm{~cm}\right)$.

\subsubsection{Methanol Stimulants}

Recovery of methane gas began to decline after day 24 (Figure 3A), while the concentration of VFAs started to increase after day 24 (Figure 3B). VFA 
concentration decreased from the beginning of incubation until day 24, while methane recovery increased at the same time. Optimum $\mathrm{pH}$ conditions during the incubation period led to a higher consumption of substrate by the methanogenic bacteria, which was produced through VFA conversion by syntrophic bacteria. This phenomenon made the syntrophic bacteria able to convert more VFAs into acetate, formate, $\mathrm{CO}_{2}$, or $\mathrm{H}_{2}$ [1]. Under conditions where $\mathrm{pH}$ was no longer optimum $(\mathrm{pH}>8)$, the methanogenesis activity of methanogenic bacteria decreased and substrate accumulated. Conversion of VFAs into substrate for methanogenic bacteria by syntrophic bacteria was no longer favorable thermodynamically, which caused the accumulation of VFAs [1].

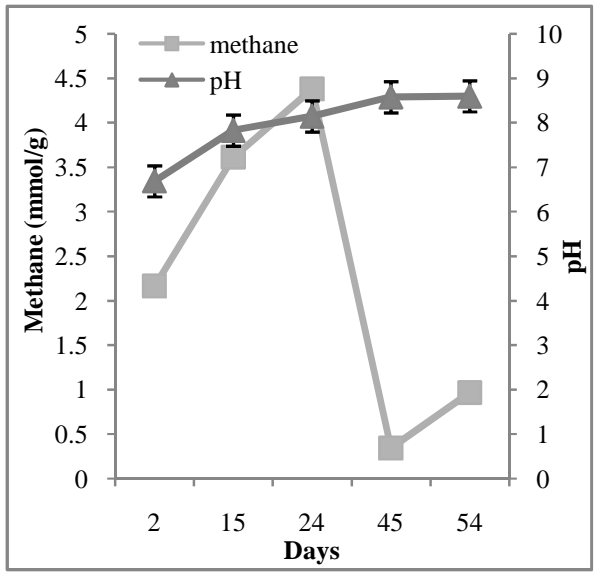

A

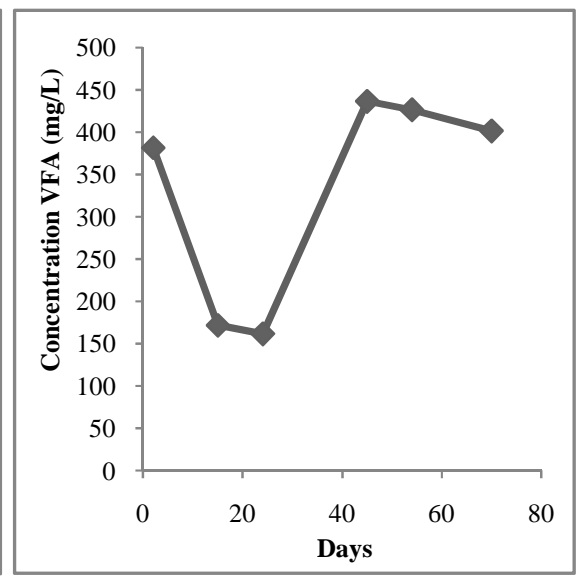

B

Figure 3 Methane production by adding methanol stimulant. A = Methane gas production; $\mathrm{B}=\mathrm{VFA}$ concentration from treatment with methanol stimulant (conditions: $\mathrm{T}=37^{\circ} \mathrm{C}, \mathrm{P}=1 \mathrm{~atm}$, anaerobic, $120 \mathrm{~mL}$ media, $15 \mathrm{~g}$ subbituminous coal, $\left.\Phi_{\text {Coal }}=0.5-1 \mathrm{~cm}\right)$

\subsubsection{Formic Acid Stimulant}

After adding the formic acid stimulant, the formation of methane was high in the early stages $(9.66 \mathrm{mmol} / \mathrm{g}$ coal until day 15$)$. The high amount of methane released may have been caused by the structure and the size of the coal chunks in this treatment, which were smaller than in the other treatments. The methanogenesis process was expected to occur after day 24 when the $\mathrm{pH}$ value began to increase, although it was still outside of optimum $\mathrm{pH}$ ranges. However, from Figure 4 we can see that a significant decrease of VFAs occurred on day 24 , when methane gas recovery reached its lowest point $(0.34 \mathrm{mmol} / \mathrm{g} \mathrm{coal})$. 


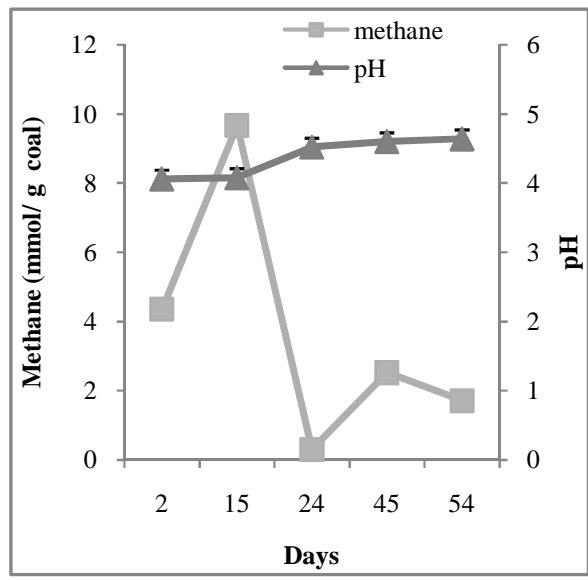

A

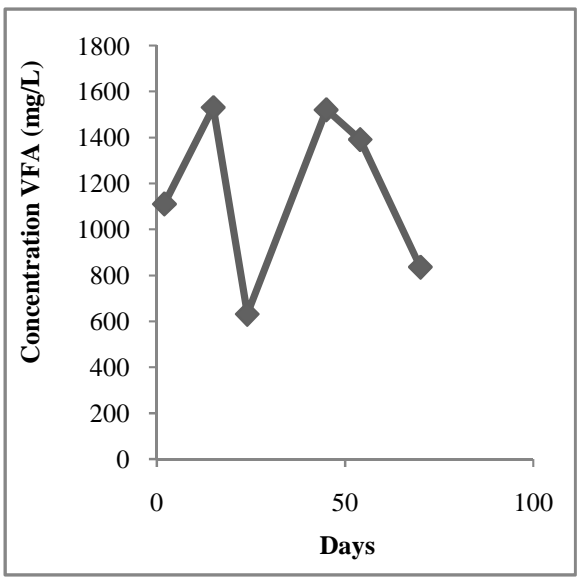

B

Figure 4 Methane production by adding formic acid. $A=$ methane gas production; $\mathrm{B}=$ VFA concentration from treatment with formic acid stimulant (conditions: $\mathrm{T}=37^{\circ} \mathrm{C}, \mathrm{P}=1 \mathrm{~atm}$, anaerobic, $120 \mathrm{~mL}$ media, $15 \mathrm{~g}$ subbituminous coal, $\Phi_{\text {Coal }}=1-2 \mathrm{~cm}$ )

Although an increase of $\mathrm{pH}$ was observed, the significant decrease in VFA levels was not accompanied by methane gas recovery. This was also the case on day 54, when decreased levels of VFAs were not accompanied by an increased level of methane gas concentration. This suggests that the majority of the methane was oxidized to $\mathrm{CO}_{2}$ by methanothroph bacteria, but further analysis should be carried out to verify this supposition.

\subsubsection{Without Stimulants}

Methane gas recovery without any addition of stimulants provided a low recovery value. The optimum $\mathrm{pH}$ for methanogenesis was 8 ; therefore the low growth of methanogenic bacteria may have been caused by the $\mathrm{pH}$ in the microcosm ( $\mathrm{pH}$ 9). Thermogenic methane inside the coal was released due to water pressure formation. This phenomenon made the concentration of detected methane fairly high on day 2 to day 15 days of the incubation period (Figure $5 \mathrm{~A})$. The decrease in the methane gas concentration from day 15 to 24 indicates that the thermogenic methane gas in the coal fractures had been released into the air and the biogenic methane had not been formed yet.

Methane gas increased after 45 days, which indicates that biogenic methane gas formation started after 45 days and was accompanied by a decrease in $\mathrm{pH}$ of the medium, approaching to $\mathrm{pH} 8.3$. Methanogenic bacteria have a wide range of 
growth $\mathrm{pH}$, with an optimum $\mathrm{pH}$ at 6-8. Only a small fraction of known methanogenic bacteria can survive under low $\mathrm{pH}$ conditions $(\mathrm{pH}=3)$ [6].

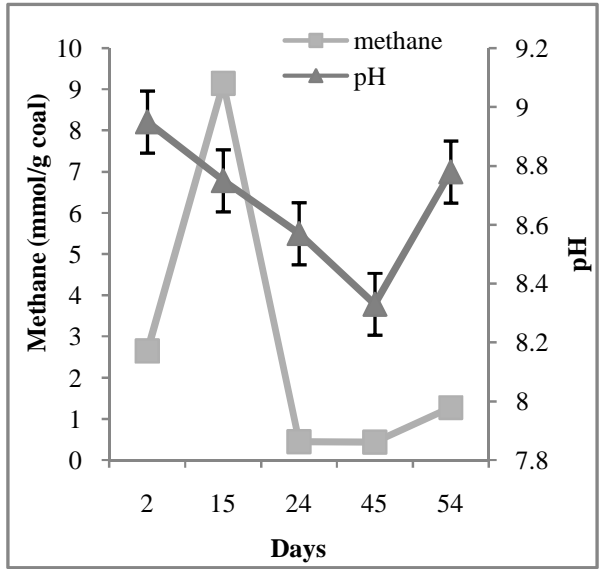

A

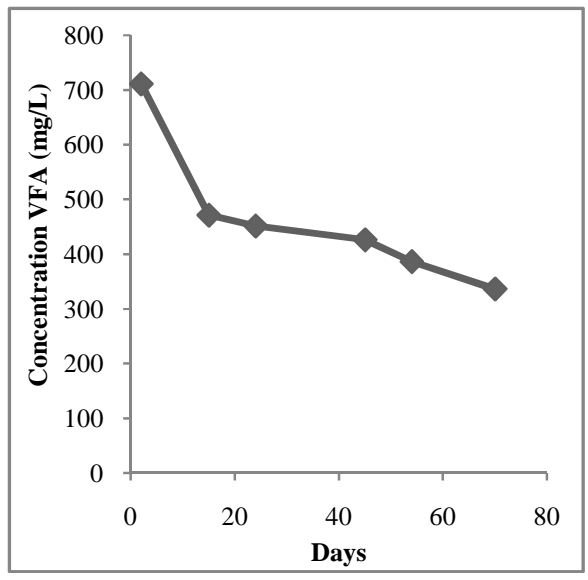

B

Figure 5 Methane production without any stimulants. A =methane gas production without any stimulants; $\mathrm{B}=$ VFA concentration from treatment without any stimulants (conditions: $\mathrm{T}=37^{\circ} \mathrm{C}, \mathrm{P}=1 \mathrm{~atm}$, anaerobic, $120 \mathrm{~mL}$ media, $15 \mathrm{~g}$ subbituminous coal, $\Phi_{\text {coal }}=0.5-1 \mathrm{~cm}$ ).

Figure 5 shows that without any stimulants, methanogenesis by methanogenic bacteria occurred very slowly, as indicated by the biogenic methane recovery enhancement, which only occurred after 45 days. This means only a small amount of acetate, $\mathrm{CO}_{2}$, and other single-carbon compounds were used in methanogenesis. The small amount of VFAs that was converted into acetate, formate, $\mathrm{CO}_{2}$, and $\mathrm{H}_{2}$ or other substrates for methanogenic bacteria, explains the not too significant decline in VFAs. The level of VFAs did not change significantly from day 15 to 70 . VFA is a substrate used by acetolastic bacteria to produce acetate, which in turn is used by methanogenic bacteria. The conversion of VFA into acetate, formate, $\mathrm{CO}_{2}$, and $\mathrm{H}_{2}$ is thermodynamically unfavorable without symbiosis with methanogenic bacteria, which use VFA conversion products to produce methane [1].

From the treatments we can conclude that adding stimulants can improve the production of biogenic methane after all of the thermogenic methane has been released. The highest biogenic methane formation $(5.4 \mathrm{mmol} / \mathrm{g}$ coal $)$ was achieved by Na-acetate addition, followed by methanol $(4.377 \mathrm{mmol} / \mathrm{g}$ coal $)$ and formic acid $(2.520 \mathrm{mmol} / \mathrm{g} \mathrm{coal})$, while the treatment without stimulants only produced $1.2 \mathrm{mmol} / \mathrm{g}$ coal methane. The decrease in VFAs had an inverse relation with the production of biogenic methane, except in the treatment with 
formic acid. The low methane production in this treatment was not followed by a decrease in VFAs as in the other treatments. The $\mathrm{pH}$ range of the treatments with Na-acetate, methanol, or without addition, during methanogenesis was between 8 and 8.8. In contrast, the treatment with formic acid caused a low initial $\mathrm{pH}$ of the microcosm (around $\mathrm{pH} 4$ ). This $\mathrm{pH}$ rate supports the growth of acetogenic bacteria that form acetate, formate, $\mathrm{CO}_{2}$, and $\mathrm{H}_{2}$ to support methane formation by methanogenic bacteria, but it is not an optimum $\mathrm{pH}$ for the growth of methanogenic bacteria [8].

\subsection{Change of Bacterial Community during Stimulation}

The presence and changes of the bacterial communities (methanogenic bacteria, syntrophic bacteria, as well as other bacteria from indigenous coal) have an important role in CBM formation [8]. This study has only analyzed the influence of the stimulation with Na-acetate and methanol on the bacterial diversity. The treatment with formic acid will not be discussed because of its low production of methane.

Fourteen samples out of 22 were used for PCR-DGGE analysis. The high inhibitor concentrations indicated by the $\mathrm{A}_{230}$ absorbance (data not shown) caused difficulty for some samples to be analyzed through PCR-DGGE. DNA amplification using nested PCR (27F-1492R primer pair) generated a 1402 bp product. The amplification products from electrophoresis can be seen in Figure 6.

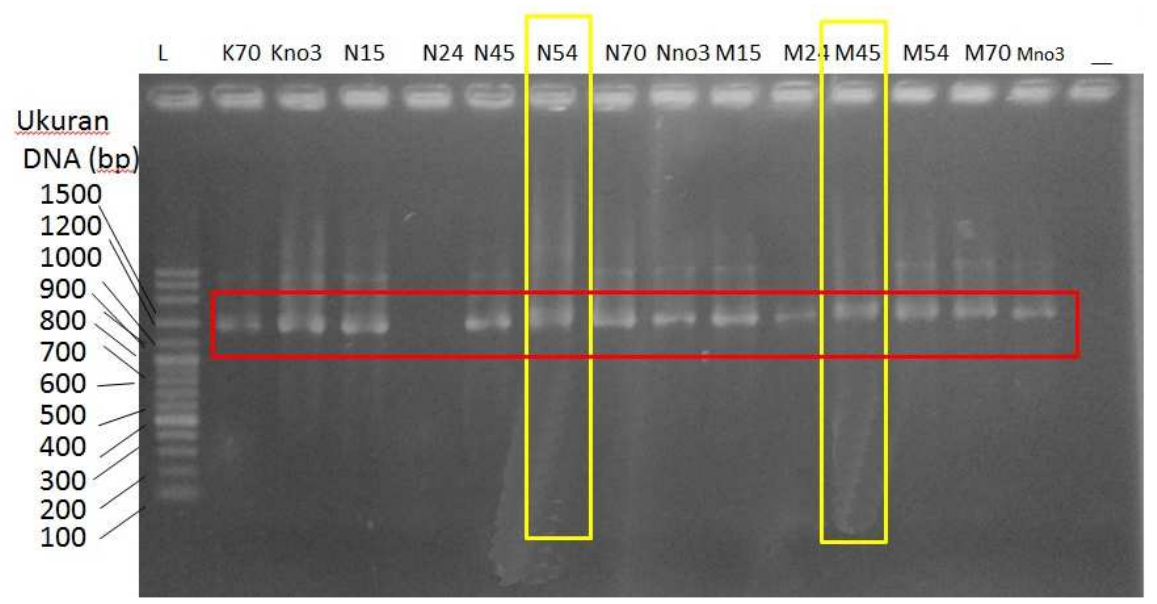

Figure 6 DNA amplification from microcosm samples with different stimulants at different incubation times $(\mathrm{L}=100 \mathrm{bp}$ ladder, $\mathrm{K}=$ without stimulants, $\mathrm{N}=\mathrm{Na}$ acetate, $\mathrm{M}=$ methanol, $-=$ negative control). Numbers $15,24,45,54,70$ : incubation time (in days), $\mathrm{NO}_{3}$ : Nitrate methanogenesis inhibitor addition). 
Figure 6 shows successful amplification of DNA template using 27F-1492R primers. The PCR product that used 27F-1492R was reamplified with three kinds of primers (338F-518R, 357F-907R, 357F-691R). Amplification of an earlier PCR product (1402 bp) using 338F_GC-518R primer for DGGE analysis is shown in Figure 7.

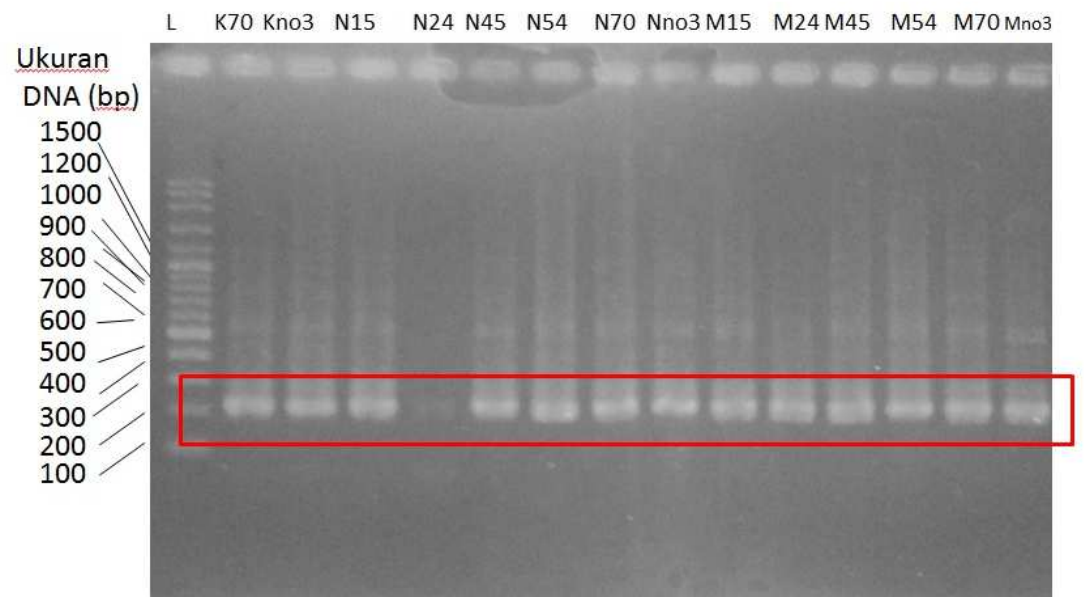

Figure 7 DNA amplification from microcosm samples (electropherogram results of re-PCR amplicons 1402bp using 338F_GC 1402-518R primers. L: 100 bp ladder, K: samples without stimulants, N: sample with Na-acetate stimulant, M: sample with methanol stimulant, -: negative control. Numbers 15, 24, 45, 54, 70: incubation time (in days). $\mathrm{NO}_{3}$ : Nitrate methanogenesis inhibitor addition.

Figure 7 shows that amplification by nested PCR using 27F-1492R and 338F_GC-518R primers and 35-60\% denaturant showed better separation of 16S rRNA genes than amplification using 357F_GC-917R primers with 35-70\% denaturant (data not shown). This is because analysis by DGGE is only optimum for DNA fragments smaller than $500 \mathrm{bp}$.

The addition of a stimulant and an inhibitor of methanogenesis $\left(\mathrm{NO}_{3}\right)$ showed an influence on the dynamic of the microbial population, as shown in Figure 8. The treatment without stimulant on day 70 (K70) and the addition of inhibitor resulted in a loss of some DNA fragments on top of the gel, which means the addition of $\mathrm{NO}_{3}$ inhibited some bacteria groups.

Addition of $\mathrm{NO}_{3}$ inhibitor basically resulted in a change of redox potential, which caused inhibition of the methanogenesis process. $\mathrm{NO}_{3}$ is a terminal acceptor electron (TAE) that has a higher redox potential value compared to $\mathrm{CO}_{2}$ or acetate (electron acceptors in the methanogenesis process). It was 
indicated that inhibitor addition, in the form of $\mathrm{NO}_{3}$, led to inhibition of several methanogenic bacteria. The addition of Na-acetate and methanol as stimulants reduced the bacteria community (less than 11 separated bands) compared to the bacterial community in the control treatment (no addition) at the end of the incubation period. This result indicates that the addition of Na-acetate only enriched a particular group of bacteria. According to Widdle, Na-acetate and methanol addition can inhibit methanotroph bacteria [9]. The present experiment has shown that Na-acetate and methanol reduce methanotrophic bacteria in the microcosm.

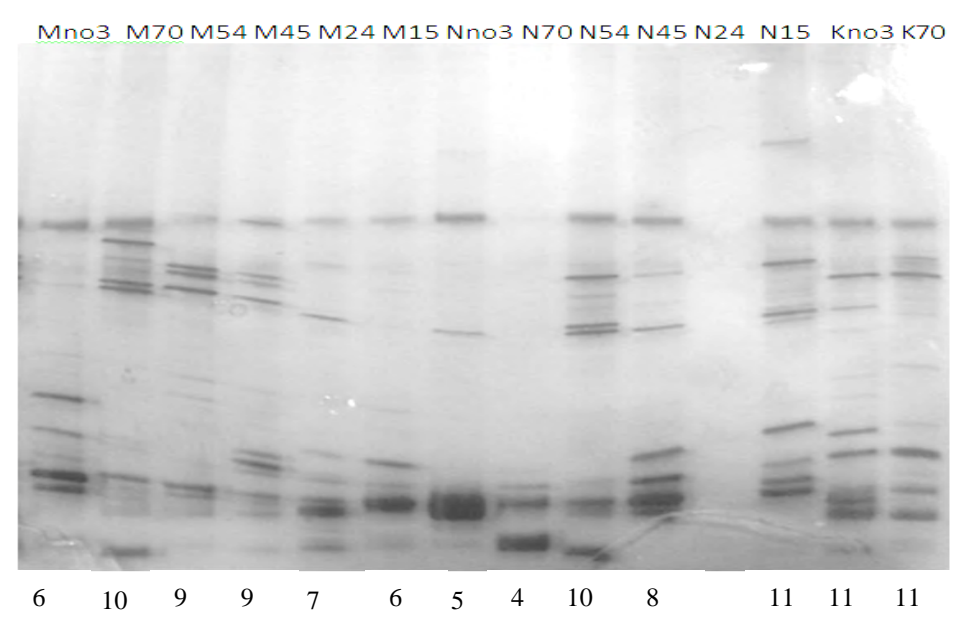

Figure 8 DGGE results of re-PCR products using 338F_GC-518R primers in order to observe microbial population dynamics in microcosm samples $(\mathrm{K}=$ without stimulants, $\mathrm{N}=$ Na-acetate stimulants, $\mathrm{M}=$ methanol stimulants). Numbers 15, 24, 45, 54, 70 indicate the incubation time (in days). $\mathrm{NO}_{3}$ : Nitrate methanogenesis inhibitor addition. Numbers below the picture refer to the total number of separated bands.

\section{Conclusion}

The highest biogenic methane formation rate was achieved by adding $\mathrm{Na}$ acetate stimulant, reaching $5.034 \mathrm{mmol} / \mathrm{g}$ coal on day 24 . The results from adding other stimulants -methanol and formic acid -showed as highest value of methane gas formation $4.377 \mathrm{mmol} / \mathrm{g}$ coal on day 24 and $2.520 \mathrm{mmol} / \mathrm{g}$ coal on day 22 , respectively. The effect of Na-acetate and methanol as stimulants on the dynamics of the bacterial population in coal bed methane was a decrease in bacterial diversity during the stimulation process. 


\section{Acknowledgements}

Thanks to Mr. Primadi H. Serad (Chief of Djarum Bakti Pendidikan Foundation) for the grant to the author, and Mrs. Ati Fatimah Syamsudin (Researcher at Geological Resource Center, Indonesian Ministry of Energy and Mineral Resources) who supported sample provision.

\section{References}

[1] Rudiansyah, I., Stimulation of Biogenic Methane Formation in Coal Bed Methane Production and Analysis of Bacterial Community Using Denatured Gradient Gel Electrophoresis Method, (Bachelor thesis), School of Life Sciences and Technology, Bandung Institute of Technology, Bandung, Indonesia, 2011.

[2] Guo, H., Yu, Z., Liu, R., Zhang, H., Zhong, Q. \& Xiong, Z., Methylotropic Methanogenesis Governs the Biogenic Coal Bed Methane Formation in Eastern Ordos Basin, China Appl. Microbiol. Biotechnocol. 96, pp. 1587-1579, 2012.

[3] Watanabe, T., Asakawa, S., Nakamura, A., Nagaoka, K. \& Kimura, M., DGGE Method for Analyzing 16s rDNA of Methanogenic Archaeal Community in Paddy Field Soil, FEMS Microbiology Letters, 232, pp. 153-163, 2004.

[4] Jones, E.J.P., Voytek, M.A., Corum, M.D. \& Orem, W.H., Stimulation of Methane Generation from Non-productive Coal by Addition of Nutrients or a Microbial Consortium, Applied and Environmental Microbiology, Nov. 2010, pp. 7013-7022, 2010.

[5] Montgomerry, H.A.C., Dymock, J.F. \& Thom, N.S., The Rapid Colorimetric Determination of Organic Acids and their Salts in SewageSludge Liquor, http://pubs.rsc.org, doi: 10.1039/AN9628700949, 1962.

[6] Bakke, I., de Schryver, P., Boon, N. \& Vadstein, O., PCR-Based Community Structure Studies of Bacteria Associated with Eukaryotic Organisms: A Simple PCR Strategy To Avoid Co-Amplification of Eukaryotic DNA, Journal of Microbiological Methods, 84, pp. 349-351, 2011.

[7] Lane, D.J., 16S/23S rRNA Sequencing. In: Nucleic Acid Techniques in Bacterial Systematics, Stackebrandt, E., \& Goodfellow, M. (eds.), John Wiley and Sons, New York, NY, pp. 115-175, 1991.

[8] Ferry, J.G., Methane from Acetate, Journal of Bacteriology, 174(17), pp. 5489-5495, 1992.

[9] Widdle, F., Kohring, G.W. \& Mayer, F., Studies on Dissimilatory SulfateReducing Bacteria that Decompose Fatty Acids III, Characterization of the Filamentous Gliding Desulfonemalimicola, Microbiology 134, pp. 286-294, 1983. 